\title{
African Studies Keywords: An Introduction
}

At the 2019 Annual General Meeting of the African Studies Review, the Editorial Review Board (ERB) adopted a Statement of Interdisciplinarity [see https://www.cambridge.org/core/journals/african-studies-review/ information/statement-of-interdisciplinarity]. The statement reaffirmed the goal of the ASR to "feature the best disciplinary and interdisciplinary work on Africa, to publish disciplinary work that is contextualized in and/or draws connections to other disciplines, and to showcase work that is readable 'across the disciplines' that contribute to African Studies." The statement also asked, what is interdisciplinary work and why it is so important to the field? The statement responds that interdisciplinary work, "draws knowledge, methods, perspectives, concepts, or theory from more than one discipline. Interdisciplinary work may combine knowledge across the academic disciplines, examine common ground or tensions between the disciplines, or deal with problems of concern across disciplines." The ERB reaffirmed its roles in producing new, informed, self-critical interaction about study methods and theoretical approaches, but we left unaddressed how to accomplish these goals and the specific role and responsibility of the journal.

With the first issue of 2021, and the launching of a new forum for interdisciplinary, cross-disciplinary, and transdisciplinary exploration and theorization, African Studies Keywords (ASK), we offer a tentative answer to these questions. On the one hand, ASK is but the latest installment of over half a century of intermittent and episodic conversations about terminology of importance and significance to African studies research. On the other hand, ASK is part of a Strategic Plan adopted in 2018 entitled "Advancing the ASA and Global African Studies." Among the plan's goals is reasserting the

This essay is the result of a set of conversations between Benjamin and Gaurav. It draws on archival work conducted by Gaurav in the SSRC archive at the Rockefeller Archive Center and on his experience co-editing with Adeline Masquelier Critical Terms for the Study of Africa (Chicago: University of Chicago Press, 2018). The curation of this series of articles is being overseen by Benjamin along with the editorial board of the journal.

African Studies Review, Volume 64, Number 1 (March 2021), pp. 116-128

(C) The Author(s), 2021. Published by Cambridge University Press on behalf of the African Studies Association

doi: $10.1017 /$ asr.2021.10 
journal's role as a touchstone for debates critical to the evolution of African studies in North America and around the globe by focusing attention on quality, inclusiveness, integrity, creativity, and accessibility. As the flagship journal of the ASA (USA), the ASR is increasingly located both in terms of editorial activity and scholarly contributions on the continent. ASK is proposed as a vehicle for the further decolonization of knowledge production by breaking down structural inequalities to access and engagement on the African continent.

This new series, which begins with Julie Livingston's essay on "The Body" [https://doi.org/10.1017/asr.2020.101], represents an attempt by the African Studies Review editorial leadership to revitalize the role of the journal in stimulating critical conversations and advancing debate. ASK is not a new anthology, but rather a re-envisioning of the journal as a living, changing, and responding forum, exploring the dynamic diversity of voices and concepts in African studies. Starting in March 2021, ASR is committed to publishing one ASK essay per issue, and we hope that over time ASK will become a core global African studies venue for interdisciplinary debate and reflection. In the following introductory essay, we reflect on three ways to think about this series, its origins and antecedents, and its promise for the future. We first explore the interdisciplinarity of African studies and the importance of collective thinking and rethinking. We then reflect on several useful antecedents to the Keywords format and consider the opportunities and limitations. Finally, we look to the future, and offer guidance to those who wish to be part of this conversation.

\section{Origins and Antecedents}

A key site of knowledge production that shapes this endeavor is the State of the Art overview essays, published in the ASR between 1980 and 1994. Supported by the Social Science Research Council (SSRC) and the American Council of Learned Societies (ACLS), these important scholarly discourses continue to be some of the most renowned in African studies. On January 30, 1984, Martha Gephardt, then a SSRC Program Officer and Staff Liaison to the joint committee on African Studies to the ACLS, sent a memo to committee members and two special consultants. ${ }^{1}$ The memo was in preparation for a special day-long session to be held later that March about what was to be done to foster and reinvigorate research in the African humanities. The questions that Gephardt wanted the attendees to consider were "(1) Where should research be going in the humanities? (2) How can we better build links between the humanities and the social sciences? (3) What are strategic entry points? (4) What are the key theoretical issues? (5) What specific projects might be planned to stimulate new research, build better links, and advance our understanding of the key theoretical issues?"2 The Humanities Planning meeting that took place on March 21, 1984, was chaired by Allen Isaacman, Professor of History at the University of Minnesota, who noted that "the impetus for the meeting is an uneven development in African 
Studies which has favored the social sciences over the humanities. He noted that the Joint Committee on African Studies has, during the past several years, adopted an interventionist perspective toward critical needs in the field of African Studies. Hence it set aside this day, preceding its regular spring meeting, to discuss ways in which the committee can use its limited resources to advance debates in the humanities and to foster links between the humanities and the social sciences in African Studies."

Harold Scheub, a scholar of African oral traditions and folklore at the University of Wisconsin, Madison, and thus an important representative from the African humanities on the committee, began by challenging the primary presupposition of the agenda: "It is necessary that we come to an understanding of the 'humanities' in an African context. The artificial divisions suggested by such terms as 'social sciences' and the 'humanities' constitute the problem. The imposition of these divisions on African experiences, materials and institutions has had the effect of making them comprehensible in non-African contexts but such indulgence may have resulted in monumental distortions." ${ }^{4}$ By pointing to artificial divisions that were more about external epistemologies than about African realities, not only was Scheub raising a critique that continues to pose challenges to those who study the continent, but he was also alluding to the project of area studies as one that was fraught with the necessary limitations of translations. Scheub went on to note: "When the Western historian finally discovers that the oral historian is an artist and that the relating of an oral history is not simply genealogical recitation but a performance, when the folklorist finds that the ancient motifs and rhythms of oral performance have a network of ties to social and political realities," only then, suggested Scheub, will we have a richer and more meaningful engagement with the practice. Another committee member, Benetta Jules-Rosette of the University of California, San Diego, who was trained as a sociologist but whose work on tourist art was just about to appear in the form of a monograph later that year, spoke to her own interests in semiotics as one way to engage in a conversation between humanists and social scientists. ${ }^{5}$ The Zairian philosopher Valentin Y. Mudimbe, who had joined the committee in 1981 and been commissioned to write a research review on African philosophy, offered to organize a series of panels on the African humanities at the next annual convention of the African Studies Association. ${ }^{6}$ Mudimbe's own interest was to foster a greater dialogue between North American and European scholars of Africa, and in particular among scholars across the Anglophone and Francophone traditions.

While the Joint Committee on African Studies considered a number of possible actions to foster and encourage a dialogue between the African humanities and the social sciences, including targeting specific humanities topics in the already successful, and in retrospect today, often path-breaking research review papers that it had commissioned, perhaps the most engaging contributions to the deliberations were made by a consultant to the committee, Ivan Karp, an anthropologist then at the Smithsonian Institution. ${ }^{7}$ 
Worried that scholars were increasingly identifying primarily with their disciplines rather than with the areas they studied, Karp cautioned against the loss of local knowledges and area-specific concerns that such affinities displayed. ${ }^{8}$ And yet, while alert to historical contingencies and local practices, Karp also insisted that Africanists be attentive to the theoretical discussions that had been taking place among humanists outside of African studies. "Our concepts of theory," he noted, "often constitute the very idea of what makes a 'field.' At the very least, the theoretical ferment that is so interesting in the humanities and that is drawing them closer to certain kinds of interpretive social science provide productive ways of relating the social sciences to the humanities. This is happening outside of African studies and it may be a measure of the parochialism of African studies specialists that they ignore the larger intellectual world of which they are part." ${ }^{9}$ Admonishing his fellow African studies colleagues for what he saw as their insularity, Karp called for four specific kinds of projects: "research that systematically related political economy and the arts and humanities;" "studies of the relations among the arts and of the critical role of performance in understanding the objects of humanistic inquiry;" "studies that examine the way and manner in which African studies draws upon an already (existing) discourse to produce its object;" and studies that can foreground the internal dynamisms, historical changes, and movements of African material cultures. "We have," Karp wrote in 1984, "very few studies, to my knowledge, of the evolution of form in the African arts. We know very little about how design is altered when the material or environment in which it is produced undergoes radical change." 10

The Joint Committee, from its initial constitution in 1960 to its eventual dissolution in 1996, played a formative role in the intellectual orientations and epistemological trajectories of North American African Studies. ${ }^{11}$ Of this long period of its existence, it was arguably the 1980s that saw the greatest innovation in Africanist research and scholarly engagement with the humanities in general and with what was being labelled "theory" in particular. As the political scientist Pearl T. Robinson (2007:257) has noted in her history of the study of Africa in the United States, "The 1980s saw the launch of a particularly successful attempt to create a new canon, one characterized by theoretical paradigms that crossed disciplinary boundaries, attention to constellations of issues germane to Africa, and a rethinking of conceptual tools and methods." Robinson notes, rightly we believe, that one of the conditions of possibility for such a re-orientation of the classic methods, tools, and epistemologies in African Studies was the increasing number of African scholars such as Mudimbe and Kwame Anthony Appiah (to name only two among a host of others) who were concurrently making their way to the North American academy. Mudimbe's central committee role and his own scholarly work in fostering the African humanities was, needless to say, the clearest instantiation of this convergence.

The Humanities Planning meeting offered an important alternative perspective to the standard narratives of area studies research being a Cold 
War phenomenon in two particular ways. ${ }^{12}$ First, as historians of the field have abundantly noted, the trajectories of African studies in the North American context far precede Cold War concerns. That trajectory begins with the study of Africa pioneered by African American and Caribbean scholars such as Alexander Crummell and Edward Blyden, followed by the more academic orientation of scholars such as W.E.B. Du Bois at historically Black institutions such as Clark Atlanta University and Howard University, and later developed through much foundation and government support at historically white universities such as Northwestern University by scholars such as Melville Herskovits (who incidentally, spent two years of his early career at Howard). ${ }^{13}$ The history of this often-fraught trajectory with competing claims for legitimacy and dominance and its eruption in 1969 in the form of a protest for equity and inclusion by African and African diasporic scholars in the institutional space of the African Studies Association is well documented (Allman 2019; Pierre 2018; McMahon 2018) ${ }^{14}$ But in addition to remembering the pre-Cold war origins of the North American study of Africa, the second point to be made here is that while Cold War interests undeniably brought funding and attention to the study of Africa, scholarship in African Studies has often exceeded if not eluded the ultimate reaches of state interests. Indeed, as the internal debates among Africanists have often shown, the scholarly acrimony generated on matters such as accepting or not accepting Department of Defense funding or engaging or not engaging in policy-related consultancies with the Department of State suggests that African studies scholars have been quite alert to the power/knowledge nexus that has historically plagued area studies research. ${ }^{15}$

A final reason for drawing attention in this discussion to the Joint Committee meeting is that the deliberations and desires of the committee are reflected very well in the substance of articles forthcoming in this new series. Not only do we bring together scholars whose disciplinary training is in the humanities with those who have been trained as social scientists, but many of the articles to follow in June, September, and December are marked by that interdisciplinary spirit to which the committee aspired. If the important 1993 volume Africa and the Disciplines: The Contributions of Research in Africa to the Social Sciences and the Humanities sought to establish the formative role of African studies in advancing theories and methodologies in the disciplines of anthropology, economics, political science, history, art history, philosophy and literary studies, the ASK essays make a similar case for the ways in which an engagement with Africa has allowed us to sharpen, re-think, modulate, and sometimes jettison the conceptual frames with which we have described, and continue to describe, Africa's pasts, presents, and futures (Bates, Mudimbe, \& O'Barr 1993).

\section{Raymond Williams and His Progeny}

A second site of knowledge production informing this new initiative in its iteration as African Studies Keywords is surely Raymond Williams' 
pathbreaking work, Keywords (1976), and its progeny. Williams' Keywords reminded scholars that our building blocks, the very essence of our theories, depend on the clarity of designated words, as well as on agreement by the scholarly community that we "know what we are talking about." In what began as an appendix to his Culture and Society (1956), Williams reminded his readers that we share meanings. As former ASR editor Carol Thompson observed in Nairobi in 2019, at the first ASK panel convened at the 3rd biennial meeting of the African Studies Association of Africa (ASAA), it may seem mundane, even trite today to recount his observations, but the words we employ are signifiers, and those who understand this or that term become part of a community. Among the most important observations, and one of the reasons why this book remains a touchstone, continues to be taught, and has never gone out of print, is that by becoming part of a community, we enter a space for debate, disagreement, and intellectual continuity. Williams elaborated by discussing how keywords have quite varying "values." He wrote, "When we come to say 'we just don't speak the same language' we mean something more general: that we have different immediate values or different kinds of valuation."

Informed by Williams' attention to "meanings and contexts," a rich genealogy of scholarship has examined not only how language reflects social and cultural formations, but also how struggles over particular terms reflect wider social struggle. Keywords, in Williams' formulation, are the elements of an active and dynamic vocabulary for research, investigation, critique, and problematization. Like many area studies fields, African studies embraced Williams' challenge, and efforts to document African studies keywords have been several and important. Space does not permit us to survey comprehensively all the developments in this realm, but here we make several observations. In South African Keywords: the Uses and Abuses of Political Concepts (1988), Emile Boonzaier and John Sharp offered a provocative meditation on the confusing and obfuscatory terminology in use during late apartheid, itself a discourse of domination. The editors turned to their colleagues in departments of anthropology, and they and the eight contributors envisioned their work as an opportunity to critically examine particular concepts, such as "tradition," "race," and "tribe," with a view to distinguishing their conventional and popular meanings from their deployment in scholarly literature and critical academic discourse. With a gentle nod to Williams, Boonzaier and Sharp envisioned a book to help readers inside and outside the academy navigate the uses and abuses of concepts such as nation, culture, development, and citizenship. Indeed, the modernity of apartheid was embedded with an ideological conceptual apparatus of classification, differentiation, and elaboration. Above all, their work was a powerful commentary on political resistance, addressing not only the state of affairs in South Africa in the mid-1980s, but also their discomfort with non-South Africans who tried to make sense of the apartheid state and its collapse with "far-fetched analogies" to struggle, class, race, and nationhood 
elsewhere. In many respects, it still reads as a commanding defense of South African exceptionalism and a narration of the large influence of anthropology in shaping the realities of the South African experience.

In New South African Keywords (2008), Nick Shepherd and Steven Robins built on the enduring legacy of Williams and of Boonzaier and Sharp but offered a new post-apartheid reconfiguration. The editors reminded us that our choice of language, words, and names actively shapes the way our social reality is constructed. The role of identifying, explaining, and conceptualizing a term is a powerful rhetorical deployment of knowledge and a site of active social contestation. Coupled with this observation, Shepherd and Robins seized upon the fact that in the first decades of the "new" South Africa, novelty, newness, and protean terminology abounded. The urgency with which the post-apartheid nation sought to rename, rethink, and reconceptualize, however, bumped up against the enabling and disabling nature of language and terminology. Just as some terms (including those featuring in the anthology two decades earlier) such as revolution, have fallen into abeyance, or are actively disembedded, such as tribe, others have percolated upward to occupy the lacunae created. As much as Boonzaier and Sharp's effort was a guide to the apartheid state and its many linguistic road bumps, Shepherd and Robins' volume is a guide to post-apartheid society constructed by leading thinkers and theorists.

In the most recent addition to the Williams school for the investigation of language, Critical Terms for African Studies (2018), Gaurav Desai and Adeline Masquelier further advanced the conversation in important ways. The editors explained that their idea was to make a case for the ways in which an engagement with Africa could allow us to sharpen, re-think, modulate, and sometimes jettison altogether the conceptual frames with which Africa has been previously studied. Inviting an engagement with twenty-five critical terms as they have been engaged and mobilized in the study of Africa, the chapters in the volume performed the concepts, often in ways that resist their normative usage. The contributors applied their terms across time and space, revealing connections and mutations to classic verbiage of social anthropology as well as other disciplinary and interdisciplinary tools, imploring readers and future generations of scholars to open their minds to new possibilities and to definitively abandon tired dichotomies and colonial inheritances. In addition, many of the contributors to the volume paid attention to and insisted on locating and juxtaposing the Anglophone terms with terms and concepts derived from African languages and epistemologies, thereby attempting to decenter the long legacy of Eurocentric bias. The essays forthcoming in this series pick up and run with a number of these important observations.

\section{A Path Forward}

The editorial board of ASR did not settle quickly or easily on the ASK series, but rather we allowed its conceptualization to unfold over several years 
through a series of conversations at conferences. What has emerged is a reflection of a long and cautious process about how to most productively reinvent the metaphorical wheel while also ensuring open-ended inclusivity, dynamism, innovation, and momentum. Before we knew what form the wheel was taking, we considered it wise to listen to and read what people wanted to share. And because the journal editorial team comprises a rolling cycle of editors, we prioritized a publication agenda in the hands of no one individual exclusively.

We intentionally launched the first sequence of the series before it had yet consolidated into anything specific. We began with an open call for papers for a panel to be convened in Nairobi at the ASAA. We solicited proposals for individual or co-authored critical scholarly essays exploring themes, topics, and ideas of interest to the ASAA conference attendees, the ASR readership, and African studies scholars globally, prioritizing submissions that reflected emerging trends in Africanist research and that used local, global, and indigenous terminologies, including words in African languages. We received many submissions, of which five were selected for Nairobi: "The Body" by Julie Livingston, "Demons" by Nathanael Homewood, "Care Labor" by Ambreena Manji, "Social Media Activism" by Mjiba Frehiwot and Chy McGee, and "Resources" by Carol Thompson. The panel was chaired by Benjamin N. Lawrance, and Christopher Ouma offered commentary and guided discussion.

The emboldening Nairobi launch led to greater interest among the ASA community as we looked toward the Boston meeting of the Association in 2019. In Boston, the journal sponsored three panels of four papers over one day, which was run as a mini-symposium in some respects, because all panelists were invited to read drafts in advance. Panel One included Phyllis Taoua on "Freedom," John Heilbrunn on "Oil," Nnamdi Elleh on "Architecture," and Mariana Dias Paes on "Law." Adeline Masquelier served as an incisive discussant and moderator. Panel Two featured Bettina Ng'weno on "The City," Meredith Terretta on "Decolonization," Melissa Graboyes and Zainab Alidina on "Malaria," and Katrina Daly Thompson and Kathryn Mara on "Autoethnography." ASR Associate Editor Benjamin Talton provided a rich and provocative discussion. Panel Three featured Paul Nugent and Isabelle Soi on "Borders," Katrien Pype and Duncan Omanga on "Digital Africa," Nic Cheeseman and Shishuwa Shishuwa on "Democracy," and Liz Thornberry on "Custom." ASR Associate Editor Claudia Gastrow shared stimulating reflection, provoking a fascinating group discussion.

Our third iteration was, like most of 2020, somewhat derailed by COVID-19. Originally, we had planned to meet in Washington, DC, but we had to rethink the format and audience for the virtual conference that unfolded. Notwithstanding the many dangers and difficulties of this moment, the ASR once again sponsored a panel featuring Kate Luongo on "Refuge," Christopher Ouma on "Pan-Africanism," Julie McArthur on "Mobility," and Abbey Warchol on "Youth." Claudia Gastrow once again offered commentary. Because our conference was virtual, authors prerecorded videos of their 
presentations and uploaded them to a common file share. You can now view the entire sequence on the ASA's YouTube site [https://www.youtube.com/ channel/UCV-V21xu5vztT-6yUmVp35A?]. Whether the papers would be submitted for review and considered by the ASR was left up to the participants. We are thrilled to begin this series with a contribution first shared in Nairobi.

These exciting developments speak to the optimism and rigor of African studies research around the globe. The ASR endeavors to feature a variety of scholarship and different types of articles, not only the classic academic-style research article but also imaginative, speculative, and disruptive writing. We also see ASK as a vehicle for the journal and the Annual Meeting to reconnect and cross-fertilize. Scholars who are interested in participating in the series are welcome to offer proposals via the online portal [https://africanstudies. $\mathrm{org} /$ publications/asr-keywords-proposal/]. While there are no fixed rules about what constitutes a keyword, or how to approach the term of art chosen, we do hope to continue the tradition of first airing a version in a public setting, a forum that provides a foundation for critical reconceptualization prior to journal submission and peer review. The spectrum of approaches offered in the State of the Art essays, the various Keywords products (including the many iterations beyond African studies that space does not permit us to survey), and more recent iterations in Desai and Masquelier, are guides, but only guides. Since the series began coalescing, numerous contributors have asked us to explain "what we want." To this we have consistently offered no answer. We prescribe any particular formula or style or none at all. We want to see what unfolds and allow authors to interpret, imagine, and envision as they see fit and are able.

Now that over twenty draft papers have been presented to the public, and a number are in the pipelines to publication, we offer some general thoughts and reflections informed by the excellent discussions led by Masquelier and others. We are seeking bold conceptual essays. In our conversations with chairs and discussants of panels we elicited an abundance of ideas and guidance. Think of this as an exercise that might result in something new, something unsettling, something generative. Make a case for your keyword, or don't: contest or resist it. Aim for iconicity rather than representativity, by which we mean, be more selective in the choice of cases you dwell on briefly. Consider making unflinching pronouncements, and do not shy from synthetic assessments and provocative questions. Create a more vivid, textured account by zeroing in on a specific case and extracting a useful lesson that humanizes the production and portrayal of your keyword. Distill some general wisdom without resolving every problem and tying all the loose ends. Offer a meditation on a term by thinking beyond your case studies and research. Fold your attempt at a keyword definition more freely and fully in the argument of the paper, and let it emerge as part of the keyword's genealogy you recount. Embrace vernacular knowledge germane to your keyword; vernacular concepts and categories that are possible pairs or simulacra for your keyword will ground your essay. Summarize key points in the relevant literature, but don't 
summarize too much; while in itself a useful exercise, summary has limitations, and one goal is to (re)instantiate your keyword.

As you put your thoughts down or dwell on a term or concept, balance the creative and artistic with academic rigor in your writing and exposition of the keyword. Write in open-ended conceptual style, one that solicits engagement, reflection, and extension, while leaving some doors open to future conversations. Think about your disciplinary biases and emphases. Place emphasis on example rather than on breadth. Keep in mind that your respective approach to your keyword reflects disciplinary discourses, and articulate an awareness of this. Question implicit and explicit oppositions and binaries that materialize in your own formulations, articulations, and interpretations. Move beyond your national, regional, ethnic, spatial, or linguistic comfort zone and site of research, and identify and incorporate data, examples, and references that appeal to many and diverse African studies scholars. Adeline Masquelier put this very well when she observed in Boston that one of the goals of this speculative and creative formula of writing is to cover thematic territory previously charted by other scholars and to do so with an eye to finding ways to shift the center of gravity of previous analyses. We look forward to hearing your thoughts and criticisms.

Benjamin N. Lawrance (D) University of Arizona

Tucson, Arizona chiefeditor@africanstudiesreview.org

Gaurav Desai University of Michigan Ann Arbor, Michigan

\section{Further Reading}

Africa Research Group. 1969. African Studies in America, The Extended Family: A Tribal Analysis of U.S. Africanists: Who They Are; Why to Fight Them. Cambridge, Mass.: October.

Akyeampong, Emmanuel. 2000. "Africans in the Diaspora: the Diaspora and Africa." African Affairs 99 (395): 183-215, https://doi.org/10.1093/afraf/99.395.183.

Allman, Jean. 2019. “\#HerskovitsMustFall? A Meditation on Whiteness, African Studies, and the Unfinished Business of 1968." African Studies Review 62 (3): 6-39. doi: 10.1017/asr.2019.40.

Atieno-Odhiambo, E. S. 1999-2000. "From African Historiographies to an African Philosophy of History." Africa Zamani 7-8: 41-89.

Barber, Karin. 1987. "Popular Arts in Africa." African Studies Review 30 (3): 23-32.

Bates, Robert H., V.Y. Mudimbe, and Jean F. O'Barr, eds. 1993. Africa and the Disciplines: The Contributions of Research in Africa to the Social Sciences and Humanities. Chicago: University of Chicago Press. 
Bayart, Jean-François. 2000. "Africa in the world: a history of extraversion," African Affairs 99 (395): 217-67. https://doi.org/10.1093/afraf/99.395.217.

Bediako, K. 2000. "Africa and Christianity on the threshold of the third millennium: the religious dimension." African Affairs 99 (395): 303-23, https://doi.org/ 10.1093/afraf/99.395.303.

Beinart, William. 2000. "African history and environmental history." African Affairs 99 (395): 269-302. https://doi.org/10.1093/afraf/99.395.269.

Ben-Amos, Paula. 1989. "African visual arts from a social perspective." African Studies Review 32 (2): 1-54.

Berry, Sara S. 1984. "The Food Crisis and Agrarian Change in Africa: A Review Essay." African Studies Review 27 (2): 59-112.

Cooper, Frederick. 1981. "Africa and the World Economy." African Studies Review 24 (2/3): $1-86$.

Coquery-Vidrovitch, Catherine. 1991. "The Process of Urbanization in Africa: From the Origins to the Beginning of Independence." African Studies Review 34 (1): $1-98$.

Desai, Gaurav. 2007. "The Scholar and the State.” The Global South 1 (1): 98-108.

Desai, Gaurav, and Adeline Masquelier. 2018. Critical Terms for the Study of Africa. Chicago: University of Chicago Press.

Feierman, Steven. 1985. "Struggle for Control: the Social Roots of Health and Healing in Modern Africa.” African Studies Review 28 (2/3): 73-147.

Freund, Bill. 1984. "Labor and Labor History in Africa: A Review of the Literature." African Studies Review 27 (2): 1-58.

Guyer, Jane. 1981. "Household and Community in African Studies." African Studies Review 24 (2/3): 87-137.

— 1996. African Studies in the United States: A Perspective. Atlanta: African Studies Association.

Isaacman, Allen. 1990. "Peasants and Rural Social Protest in Africa." African Studies Review 33 (2): 205-317.

Jewsiewicki, Bogumil. 1989. "African Historical Studies: Academic Knowledge as 'Usable Past' and Radical Scholarship.” African Studies Review 32 (3): 1-76.

Jules-Rosette, Benetta, 1984. The Messages of Tourist Art: An African Semiotic System in Comparative Perspective. New York: Plenum Press.

Karp, Ivan. 1997. "Does Theory Travel? Area Studies and Cultural Studies." Africa Today 44 (1997): 281-95.

Lonsdale, John. 1981. "States and Social Processes in Africa: A Historiographical Survey.” African Studies Review 24 (2/3): 139-226.

Luckham, Robin. 1994. "The Military, Militarization and Democratization in Africa: A Survey of Literature and Issues." African Studies Review 37 (2): 13-75.

Mabogunje, Akin L. 1990. "Urban Planning and the Post-Colonial State in Africa: A Research Overview.” African Studies Review 33 (2): 121-203.

Malowany, M. 2000. "Unfinished agendas: writing the history of medicine of subSaharan Africa." African Affairs 99 (395): 325-349. https://doi.org/10.1093/ afraf/99.395.325.

Mamdani, Mahmood. 1990. "African Studies, Made in the U.S.A." CODESRIA Bulletin 2: $7-10$.

Martin, William G., and Michael O. West. 1999. "The Ascent, Triumph and Disintegration of the Africanist Enterprise, U.S.A." In Out of One, Many Africas: Reconstructing the Study and Meaning of Africa, edited by William G. Martin and Michael O. West, 85-122. Urbana: University of Illinois Press. 
McGaffey, Wyatt. 1981. "African Ideology and Belief: A Survey.” African Studies Review $24(2-3): 227-74$.

McMahon, Elisabeth. 2018. "Liberation." In Critical Terms for the Study of Africa, edited by Gaurav Desai and Adeline Masquelier, 202-15. Chicago: University of Chicago Press.

Mudimbe, Valetin Y. 1985. "African Gnosis: Philosophy and the Order of Knowledge: An Introduction.” African Studies Review 28 (2/3): 149-233.

— 1988. The Invention of Africa: Gnosis, Philosophy and the Order of Knowledge. Bloomington: Indiana University Press.

Pierre, Jemima. 2018. “Africa/African.” In Critical Terms for the Study of Africa, edited by Gaurav Desai and Adeline Masquelier, 12-36. Chicago: University of Chicago Press.

Robinson, Pearl T. 2007. "Area Studies in Search of Africa: The Case of the United States." In The Study of Africa, Vol 11: Global and TransnationalEngagements, by Paul Tiyambe Zeleza, 235-76. Dakar: CODESRIA.

Scheub, Harold. 1985. "A Review of African Oral Tradition and Literature." African Studies Review 28 (2/3): 1-72.

Szanton, David L. 2004. "Introduction: The Origin, Nature and Challenges of Area Studies in the United States." In The Politics of Knowledge: Area Studies and the Disciplines, edited by David L. Szanton, 1-33. Berkeley: University of California Press.

Vansina, Jan. 1994. Living with Africa. Madison: University of Wisconsin Press.

Vaughan, Megan. 1994. "Colonial Discourse Theory and African History, or Has Postmodernism Passed Us By?” Social Dynamics 20 (2): 1-23.

Zeleza, Paul T. 2003. "Historicizing the Posts: The View from African Studies." In Postmodernism, Postcoloniality and African Studies, edited by Zine Magubane, 1-37. Trenton, New Jersey: Africa World Press.

Zewde, B. 1999-2000. "African historiography: Past, Present, and Future." Africa Zamani 7-8: 33-40.

\section{Notes}

1. The committee members who attended the meeting were Allen Isaacman, Benetta Jules-Rosette, V.Y. Mudimbe, Jane Guyer, Thandika Mkandawire, Michael J. Watts, Harold Scheub, and Fassil G. Kiros. The two consultants were Ivan Karp and Paul Riesman.

2. Martha Gephardt, "Memo," dated Jan 30, 1984, Folder 98, Box 18, G1, A1, S1, SSRC Records, Rockefeller Archive Center. Gaurav Desai thanks and acknowledges the support from the Rockefeller Archive Center to undertake research in the SSRC and Ford Foundation records.

3. "Notes on March $21^{\text {st }}$ Humanities Planning Meeting," Folder 100, Box 19, G1, A1, S1, SSRC Records, Rockefeller Archive Center.

4. "Memo for the SSRC Humanities Planning Meeting," Harold Scheub, March 12, 1984, Folder 98, Box 18, G1, A1, S1, SSRC Records, Rockefeller Archive Center.

5. Benetta Jules-Rosette, "Suggestions for the Humanities Planning Committee," Folder 98, Box 18, G1, A1, S1, SSRC Records, Rockefeller Archive Center. See also, Jules-Rosette, 1984. 
6. "Notes on March 21st Humanities Planning Meeting," Folder 100, Box 19, G1, A1, S1, SSRC Records, Rockefeller Archive Center. See Mudimbe 1986. It was later revised and incorporated in his prize-winning 1988 book, considered by many to be a paradigm-shifting contribution to the study of the African humanities.

7. Some topics for future research review papers included "the psychological dimension in African Studies, e.g., the African Oedipus, African music, Christianity in Africa." See "Notes on March 21st Humanities Planning Meeting", Folder 100, Box 19, G1, A1, S1, SSRC Records, Rockefeller Archive Center. See also, Ivan Karp, "Memo," Feb 22, 1984, Folder 100, Box 19, G1, A1, S1, SSRC Records, Rockefeller Archive Center.

8. So, he argued, "Graduate training has increasingly become centered on the acquisition of disciplinary skills and fledgling researchers often define themselves as anthropologists, political scientists or art historians first and Africanists second. An extreme, though not uncommon form for this orientation to take is the claim that the where of the research is irrelevant-that migration is the issue whether it is studied in West Africa or the Amazon Basin." Ivan Karp, "Memo," Feb 22, 1984, Folder 100, Box 19, G1, A1, S1, SSRC Records, Rockefeller Archive Center.

9. Karp, "Memo." The debates about the role of theory and postmodern thought in African Studies continued to echo into the late twentieth century. Two markers are Vaughan 1994 and Vansina 1994. See Karp's own thoughts on the matter a decade after the meeting, in Karp 1997. Also, Zeleza 2003.

10. Karp, "Memo."

11. The joint committee was originally set up to administer a three-year program of grants for research by individuals on Africa south of the Sahara funded by the Ford Foundation. In 1962, the Ford Foundation renewed support for another three-year period. The purview of the committee, its activities, and scope changed over time, and its archives housed at the Rockefeller Archive Center in Sleepy Hollow, New York, provide a dynamic picture of the academic debates, tensions, and negotiations that Africanists who served on the committee made as the field developed and expanded.

12. This is by no means to discount the significant role of Cold War interests in the funding of African Studies. It is only to suggest that work in African studies often exceeded the interests and goals of such funding. For a critical expose of the funding of African Studies, see Africa Research Group 1969. See also Mamdani 1990, and Szanton 2004, for an alternative accounting of the work of area studies.

13. See Robinson 2007; Martin \& West 1999.

14. For first-hand accounts and perspectives on the Montreal meeting, see the Special Issue of Africa Today entitled "Crisis in African Studies," Africa Today, Oct-Nov-Dec 1969, Vols 16, nos. 5\&6.

15. For some voices in the debate, see the articles in the special issue of African Issues titled "Identifying New Directions for African Studies," African Issues, vol 30, no 2 (2002), Guest Editor: Larry W. Bowman. For an overview of the debate, see Desai 2007. On the divisions among Africanists on policy-related work, see Guyer 1996. 